\title{
Microbial Diversity in Post-Mining Land in Makroman Kelurahan, Sambutan District Samarinda City
}

\author{
Sopialena Sopialena* \\ Program of Plant Pest and Disease, Faculty of Agriculture, University of Mulawarman, Jl. Pasir Balengkong \\ Gunung Kelua, Samarinda 75119, East Kalimantan, Indonesia. Tel: +62-541-749161, Fax: +62-541-738341 \\ Corresponding author. Email: sopialena88@gmail.com
}

\begin{abstract}
East Kalimantan is one of the areas rich in mining land, one of which is coal. Coal mining activities in Kaltim are generally carried out with open mining techniques, namely by clearing land, peeling top soil, moving the top layer of soil, and then mining coal. This technique results in physical, chemical and biological damage to the soil, making it unsuitable for plant growth because it is poor in nutrients. The purpose of this study was to identify the available microorganisms in the soil of ex-coal mining. Soil sampling was carried out at the post-mining area in Makroman Village, Sambutan District, Samarinda City. Soil samples were taken with a depth of $\pm 30 \mathrm{~cm}$. Soil is taken \pm weighing $1 \mathrm{~kg}$. Then put it in a plastic bag and label it. The soil sample is then taken to the laboratory. The media used were Potato Dextrose Agar media for culturing fungi and Nutrien Agar media for culturing bacteria. The nematodes were identified using extraction of soil samples used was the Baermann funnel method. The results showed that the types of fungi obtained based on the results of the study contained 4 (four) different types of fungi, namely Trichoderma sp., Penicillium sp., Fusarium sp., and Aspergillus sp.; There are two types of bacteria, the first is round bacteria (Coccus) and has a gram negative, the second type is rod-shaped bacteria (Bacilli) and has a gram negative; and there was only one type of nematode, namely Pratylenchus sp.
\end{abstract}

Keywords: Microorganism, Ex-coal mining land soil.

\section{INTRODUCTION}

Mining activities cause damage to the physical, chemical and biological properties of the soil. Mining activities can cause changes in soil structure due to excavation of top soil to reach deeper layers of mining material. The construction of dams (dug holes/dams) has changed the topography and composition of the surface soil, due to the use of overburden soil layers as a means of stockpiling. On ex-mining land, it appears in the form of a pit (which is in the form of a small lake with a depth of up to $40 \mathrm{~m}$ ), heaps of excavated clay (overburden), and a stretch of taling (remaining washing of minerals) in the form of swamp or dry land. indicated that over time, the tailings stockpile will form a wider tailings bed. The research results of Pribadi (2012) [1].

In ex-coal mining areas, the main problem that arises is environmental change. Chemical changes mainly have an impact on groundwater and surface water, followed by physical changes in the morphology and topography of the land. Furthermore, changes in microclimate are caused by changes in wind speed, disturbance of biological habitats in the form of flora and fauna, as well as a decrease in soil productivity with the result that it becomes barren or barren [2]. Characteristics of excoal mining land include open space, high temperature, low soil $\mathrm{pH}$, no vegetation, and degradation of soil microorganisms [3].

In addition, it also affects the balance of the soil surface ecosystem, reduces soil productivity and environmental quality. The land surface becomes irregular, soil fertility is low and prone to erosion so that the carrying capacity of the soil for plants is low [4]. The topsoil is replaced by soil from the less fertile lower layer, whereas the fertile topsoil is in the lower layer. Likewise, the biological population of the soil in the topsoil becomes submerged, so that it disappears or dies and does not function properly [5].

The low activity of soil microbes is due to the influence of various microbial environmental factors such as a decrease in soil $\mathrm{pH}$, soil moisture, organic matter content, soil holding capacity to water and soil structure. The presence of soil microbes is very potential in the development and survival of plants. Microbial activity is not only limited to providing nutrients, but also plays a role in decomposing litter and can gradually improve soil structural properties [6].

Based on the description above, it can be seen that the negative impact of mining is the number of microorganisms that are lost and die in the soil. Until now, there has not been much research specifically on what microorganisms can survive in mining soil. 
Therefore, it is necessary to identify what microorganisms are found in the soil of post-coal mining land so that it becomes the basis for microbial investment in the land to improve the soil microbial structure. This study aims to determine the types of microorganisms in post-coal mining land in Makroman Village, Sambutan District, Samarinda City.

\section{RESEARCH METHODS}

Samples of ex-coal mining soil were taken at CV post-mining land. Arjuna in Makroman Village, Sambutan District, Samarinda City. (b) for identification of microbes in the Plant Disease Pest Science Laboratory, Faculty of Agriculture, Mulawarman University. The materials used in this study were mine soil samples, potato dextrose agar (PDA), sodium agar (NA), formalin, aquades, alcohol, and methylene blue.

Soil sampling was carried out at the postmining area of CV. Arjuna in Makroman Village, Sambutan District, Samarinda City. Soil samples were taken with a depth of $\pm 30 \mathrm{~cm}$. Soil is taken \pm weighing $1 \mathrm{~kg}$. Then put it in a plastic bag and label it. The soil sample is then taken to the laboratory. The media used were Potato Dextrose Agar (PDA) media for culturing fungi and Nutrien Agar (NA) media for culturing bacteria.

\subsection{Fungal and Bacterial Isolation}

The soil sample was weighed $1 \mathrm{~g}$ and then put in a test tube containing $10 \mathrm{ml}$ of sterile distilled water, then shaken, after that $1 \mathrm{ml}$ of the solution was taken and put into a test tube containing $9 \mathrm{ml}$ of sterile distilled water. This is repeated until it reaches a dilution level of 10-3. The results of the dilution were then taken $1 \mathrm{ml}$ to be injected into a petri dish containing solid PDA media to see fungal growth and injected $1 \mathrm{ml}$ into a petri dish containing NA to see bacterial growth. Then glued with plastic wrap. Finally, the petri dishes were incubated at room temperature $27-28^{\circ} \mathrm{C}$ for $2-3$ days, after which observations were made on petri dishes. Then make preparations from the mushrooms that have grown, take a little using an ose needle to be placed on a glass object, then add methylene blue liquid and cover with a cover glass. Furthermore, identification by observing the morphological characteristics of colony color, hyphae type, spore shape and spore size [7].

The shape of the bacterial cells and the color of the bacteria growing on the petri dish can be done by gram test using the Hucer method (differential staining) according to $\mathrm{RN}$ in the method book for bacteriology. Gram staining is an empirical method to distinguish bacterial species into two major groups, namely gram positive and gram negative, based on the chemical and physical properties of the cell wall.

\subsection{Nematode Isolation}

Extraction of soil samples used was the Baermann funnel method. Wrap the soil sample weighing \pm 100 grams using tissue, the packaging is done in such a way that the soil sample does not scatter when placed in the funnel. The cut hose is attached to the stem of a funnel and the end of the hose is tied with a rubber band. The gauze is placed on the funnel, then the soil sample is placed on top of the gauze on the funnel and then water is added until the soil sample is submerged. This soil sample was incubated for $3 \times 24$ hours. After incubation, the water in the hose is inserted into the film tube, and 3 drops of $5 \%$ formalin are added and fixed for 1 minute.

\section{RESULT AND DISCUSSION}

\subsection{Overview of Research Sites}

The research location is administratively located in Makroman Village, Kec. Foreword Samarinda City, East Kalimantan Province is located between $117^{\circ} 14^{\prime} 30.00^{\prime \prime}$ to $117^{\circ} 30^{\prime} 12.70^{\prime \prime}$ East Longitude and $0.00^{\circ} 0{ }^{\prime} 33^{\prime \prime}$ to $00^{\circ} 5^{\prime} 00^{\prime \prime}$ South Latitude. The area of Makroman Village is about $12.27 \mathrm{~km} 2$, the position of Makroman Village is directly adjacent to Pulau Atas in the north, Sambutan in the east, Sei Kapih in the south, and Sei Pinang Luar in the west.

\subsection{Types of Microorganisms}

3.2.1. Fungi Found at Post Coal Mining Land in Makroman Village.

3.2.1.1. Trichoderma sp. 


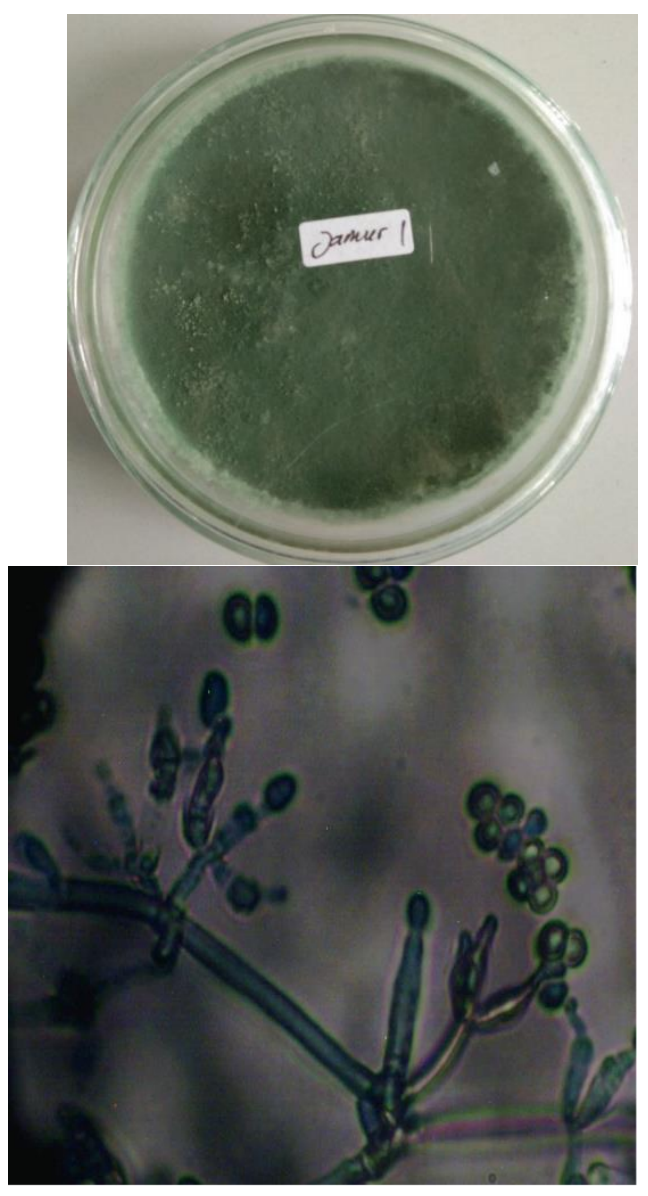

Figure 1. Trichoderma sp.

Based on macroscopic observations. It can be seen that the color of the fungal colonies on the first day was white. On the third day, the color of the colonies had completely changed from light green to dark green, and grew evenly in the petri dish (Figure a). Microscopic observations showed that the hyphae were insulated, the conidia were round or oval, smooth-walled, and the phialids looked long (figure b). Colonies of Trichoderma sp. In the medium at first it looks white then the mycelium will turn greenish then it looks mostly green in the middle of the colony surrounded by mycelium which is still white and in the end the whole medium will be green [8].

Colonies on the medium reached a diameter of more than $5 \mathrm{~cm}$ within 9 days, initially hyaline in color, then turned greenish white and then faint green, especially in the part that showed a lot of conidia. Conidiphores can be branched like a pyramid, namely at the bottom of the lateral branch which is repeated, while towards the end of the branch it becomes shorter. The phialids are slender and long, especially at the apex of the branch, and measure (2.8-3.2) $\mathrm{m} \times(2.5-2.8) \mathrm{m}$, and are smoothwalled. Chlamydospores are generally found in the mycelia of old colonies, are intercalated, sometimes terminal, generally round, hyaline in color, and smooth-walled [9].
According to Nurhayati (2001) Trichoderma sp. is one of the most widespread (cosmopolitan) soil fungi, which is commonly found in agricultural lands. This fungus is also found on the root surface of various plants, on rotten bark, especially wood that is attacked by fungus. Trichoderma sp. known as saprophytic fungi that live in the soil, especially on organic matter, in litter and dead wood. In general, Trichoderma sp. live in slightly humid areas. Meanwhile, in dry soil conditions, the population of Trichoderma sp. will decrease after quite some time.

According to Alexopoulos and Mims (1979) the classification of Trichoderma sp. are as follows: Kingdom: Fungi; Division: Amastigomycota; Class: Deuteromycetes; Order: Monilialles; Family: Moniliaceae; Genus: Trichoderma; Species: Trichoderma sp.

\subsubsection{Penicillium sp.}

Based on macroscopic observations, it can be seen that the color of the fungal colonies was greenish white with the surface of the colonies like cotton (figure a). Microscopic observations, (figure b) were insulated hyphae, round conidia, lanceolateshaped phyalids, single conidiophores and broomlike spore heads.

According to Alexopoulos and Mims (1979), Penicillium sp. has a greenish-white color with a colony surface like cotton and has round green conidia, smooth and solid colony surface and flat colony shape. Microscopic observations showed Penicillium sp. It has round pink conidia and cylindrical phialides with metula. 


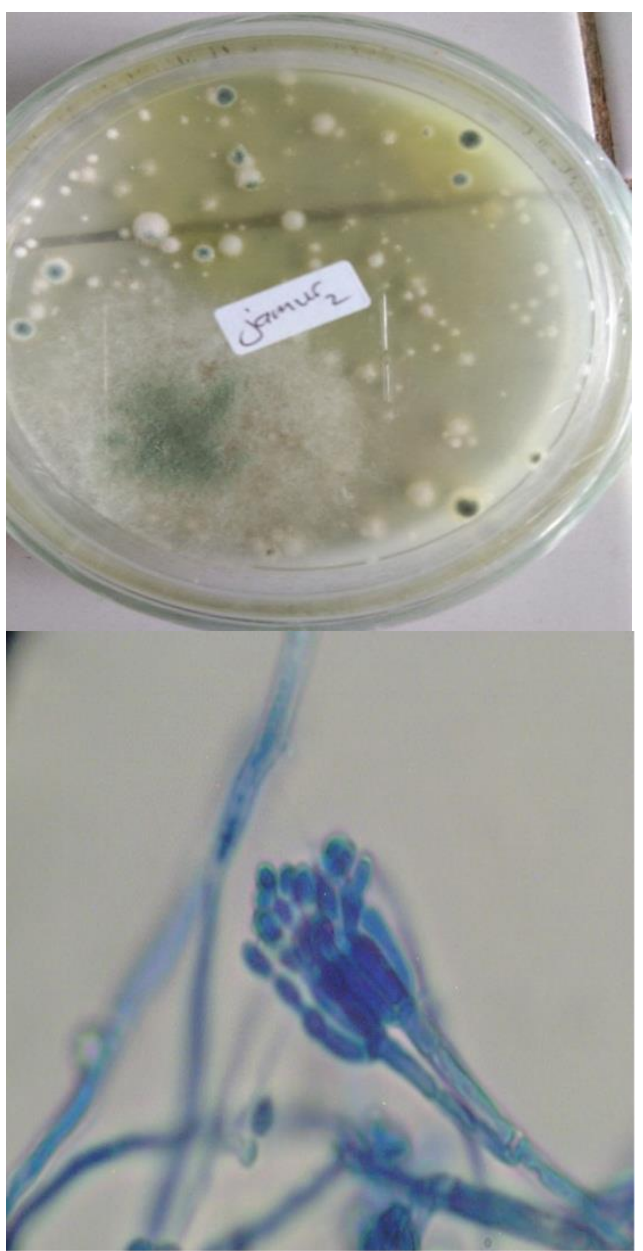

Figure 2. Penicillium sp.

Specific characteristics of Penicillium sp. are insulated or septate hyphae. Branched mycelium, usually colorless, conidiophores insulated and appearing above the surface, originating from hyphae below the surface, branched or unbranched. The spore-bearing head is shaped like a broom with the sterigmata appearing in clusters, the conidium forming chains as they emerge one by one from the sterigmata. Conidium when young is green, then turns bluish or brownish.

Penicilliumsp. have vegetative hyphae called air hyphae. Penicillium sp. reproduce sexually by forming spores produced in a sac (ascus) called ascospores and asexually by forming conidiospores, ie spores produced in chains at the tips of hyphae. Conidiospore cell forms in the fungus Penicillium sp. is like a bottle with a long or short neck, this mushroom is bluish green. Penicillium sp. widely used in industry to produce antibiotics, for example penicillin produced by $P$. nonatum and $P$. chrysogenum.

Peniciliumsp. classified according to the binomial name system, namely Kingdom: Fungi; Phylum: Ascomycota; Class: Euromycetes; Order: Eurotiales; Family: Trichocomaceae; Genus: Penicillium; and Species: Penicillium sp [9].

\subsubsection{Fusarium sp.}

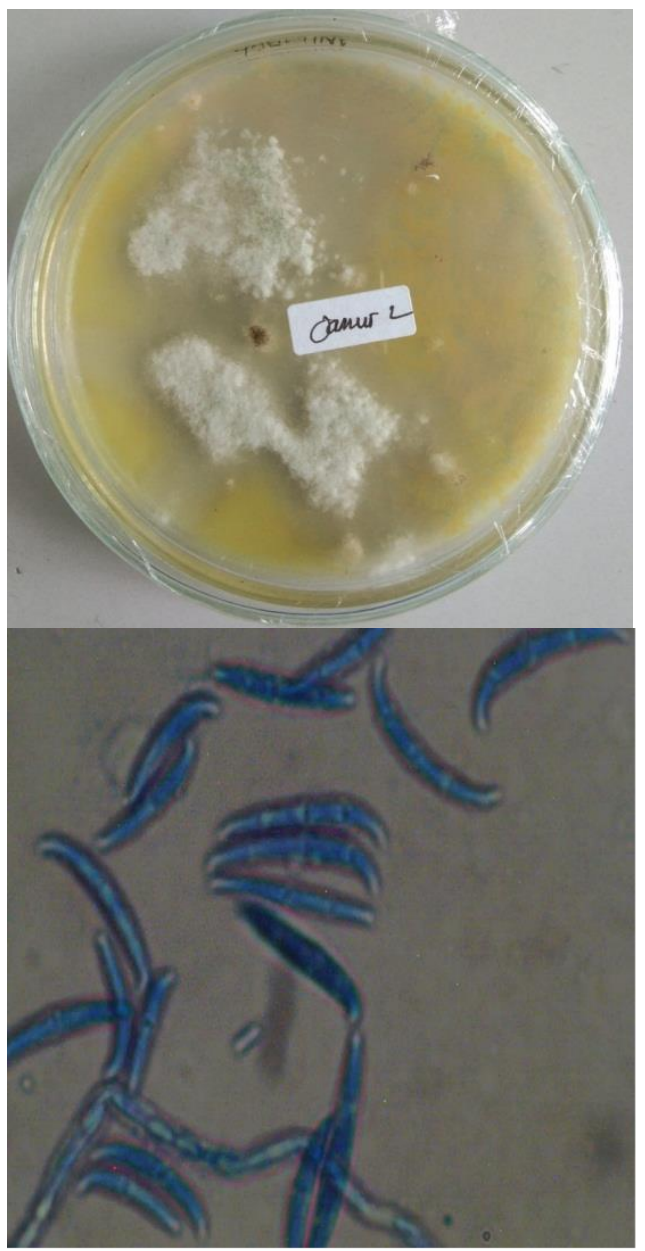

Figure 3. Fusarium sp.

Based on the results of macroscopic observations, the fungal colonies of Fusarium sp. white color on the third day, after the fourth day onwards the color of the colony changes to yellowish white to orange (figure a), microscopic observation is that the hyphae are insulated, have two types of conidia, namely microconidia and macroconidia which are crescent-shaped (figure b) .

Fusarium sp. on PDA media macroscopically it has white colonies and microscopically it has insulated hyphae, has two types of conidia, namely microconidia and macroconidia. The results of these observations are in accordance with that proposed by Robert et al (1984), the fungal colony of Fusarium sp. usually fast growing, off-white or brightly colored such as yellow, pink, brownish, reddish, violet or purple in color having microconidia and macroconidia [10].

Fusarium sp. have microconidia and macroconidia shaped like a crescent moon, canoe, or slightly turned and tapered ends. Macroconidia vary in number of septa and are hyaline. The conidia are often assembled in elliptical or slightly rounded structures. According to Alexopoulos and Mims (1979) Fusarium sp. It has many septa and is 
crescent or canoe-shaped. According to Alexopoulos and Mims (1979) structures such as heads with an elliptical or slightly rounded shape contain conidia.

According to Robert et al (1984), the fungus Fusarium sp. generally can be parasitic to some food crops. Most of the Fusarium sp. is a soil fungus and spreads almost all over the world, some are plant parasites, causing root and stem rot, vascular wilt and fruit rot. There are even some species that are known to be pathogenic to humans and animals, and are major toxin producers.

According to Alexopoulos and Mims (1979), the classification of the fungus Fusarium sp. are as follows: Kingdom: Fungi; Division: Amastigomycota; Class: Deuteromycetes; Order: Moniliales; Family: Tuberculariaceae; Genus: Fusarium; Species: Fusarium sp.

3.2.1.4. Aspergillus $\mathrm{sp}$.

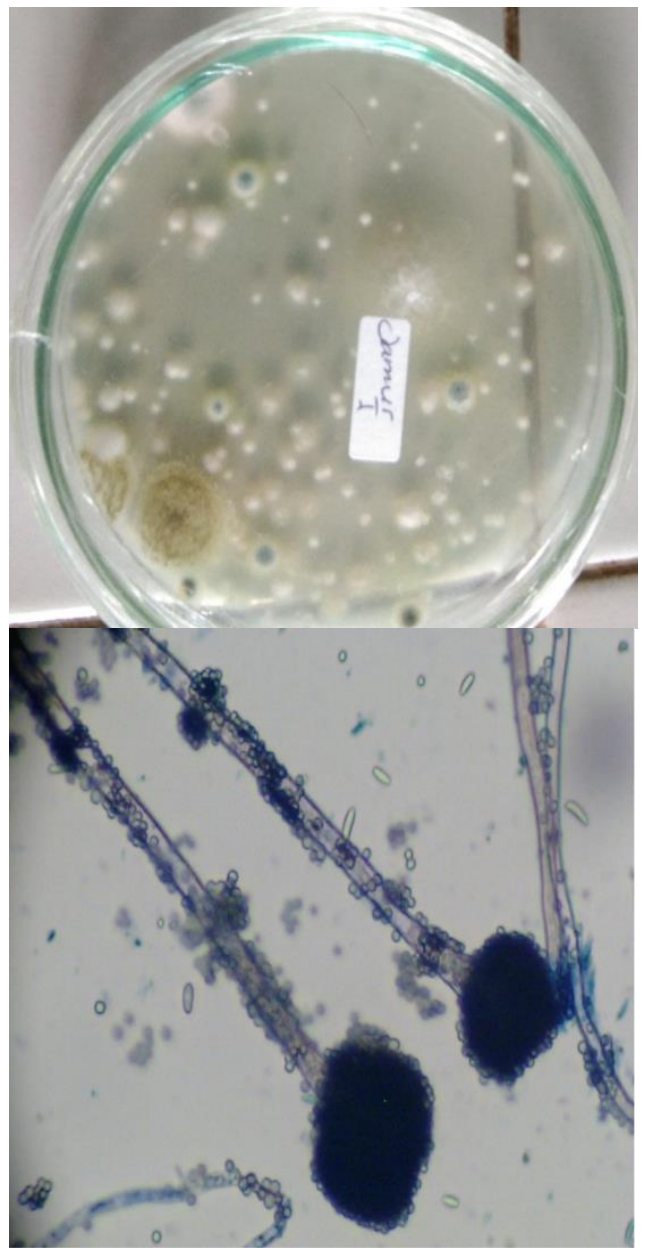

Figure 4. Aspergillus sp.

Based on macroscopic observations, it can be seen that the color of the colonies produced by this fungus on the third day is dark brown, on the fourth day and so on the colony color changes to blackish brown (figure a). While microscopic observations, it is seen that this fungus has long conidiophores, and has round conidia (figure b). According to Black (1999), the fungus Aspergillus sp. is one of the most common and easily identifiable species of the genus Aspergillus. This fungus has a white or yellow base coat with a thick layer of dark brown to black conidiospores [11]. The head of the conidia is black, round, tends to separate into looser parts with age. Conidiospores have smooth walls and are brown in color. In its growth Aspergillus sp. In direct contact with the nutrients contained in the substrate, simple molecules around the hyphae can be directly absorbed while more complex molecules must be broken down before being absorbed into the cell, by producing several extracellular enzymes.

Robinson (2001) mentioned that Aspergillus sp. has a characteristic that has primary and secondary sterigma because the phialides branched 2 times. Aspergillus sp. can grow rapidly, producing aerial hyphae bearing the characteristic conidia structure of long conidiospores with terminal vesicles with phialids producing basipetal chains of conidia. Aspergillus sp. is one of the most common and easily identifiable species of the genus Aspergillus. Aspergillus niger can grow rapidly at temperatures of $35^{\circ} \mathrm{C}-37^{\circ} \mathrm{C}$ (optimum), $6^{\circ} \mathrm{C}-8^{\circ} \mathrm{C}$ (minimum), $45^{\circ} \mathrm{C}-47^{\circ} \mathrm{C}$ (maximum) and requires sufficient oxygen [12].

According to Alexopoulos and Mims (1979), the classification of Aspergillus sp. are as follows: Kingdom: Fungi; Division: Amastigomycota; Class: Ascomycetes; Order: Eurotiales; Family: Euroteaceae; Genus: Aspergillus; Species: Aspergillus sp.

\subsubsection{Bacteria Found in Post-Coal Mining Soil in Makroman Village.}

Based on the results of gram staining that has been isolated from post-mining soil in Makroman Village, bacteria are obtained, namely Bacill bacteria Gram Negarive and Coccus Bacteria Gram Negatif.

According to Campbell (2009), a bacterial cell colony is a group of cell masses that can be seen with the naked eye. All cells in the colony are the same and all cells are considered as progeny of one microorganism and therefore represent pure culture. The appearance of bacterial colonies in agar plate shows the typical shape and size of the colonies, which can be seen from the overall shape of the appearance of the colony, the edges and the surface of the colony. It can also be seen from the elevation of bacterial colonies which can be flat, raised, convex, drop-like, button-like, hilly, growing into the medium, and crater-like.

Bacterial colonies have various shapes, including round, round with shell edges, round with raised edges, wrinkled, concentric, irregular and spreading, threadlike, L-shaped, round with spreading edges, filliform, rhizoid and complex. The edges of bacterial colonies are smooth, wavy, grooved, irregular, brush, branched, like wool, like thread and like hair tie. While the elevation is flat, 
raised, convex, like a button, hilly, growing into the medium and like a crater [13].

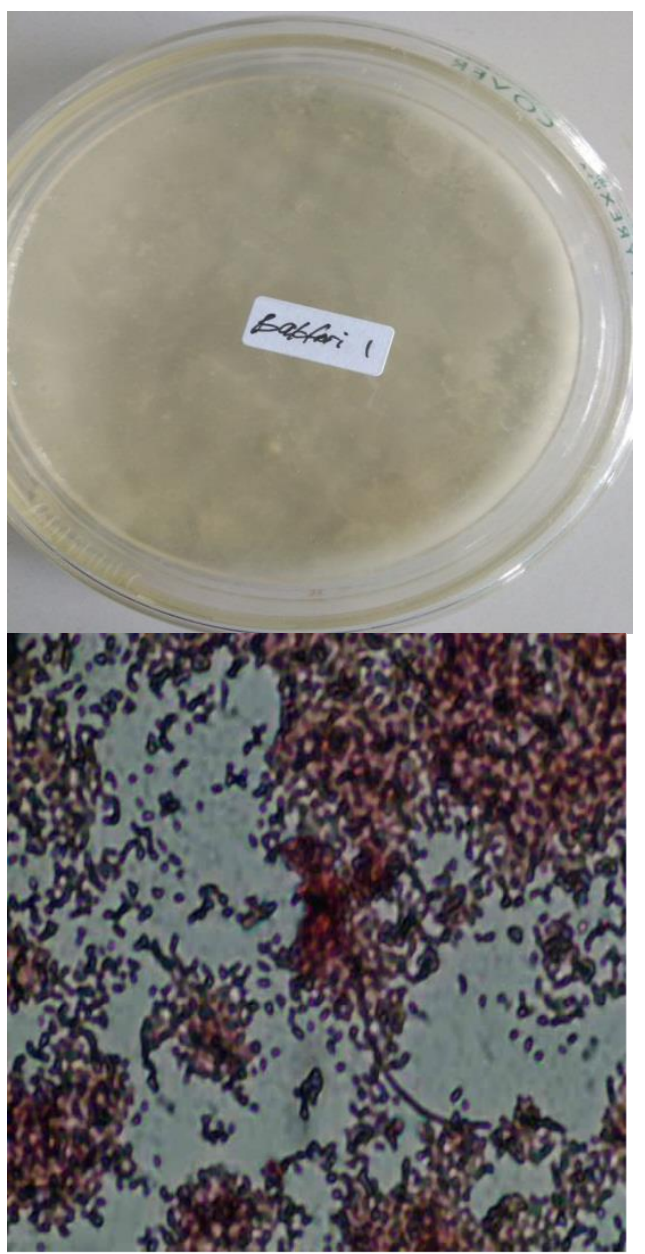

Figure 5. Bacilli bacteria with negative red color (gram).

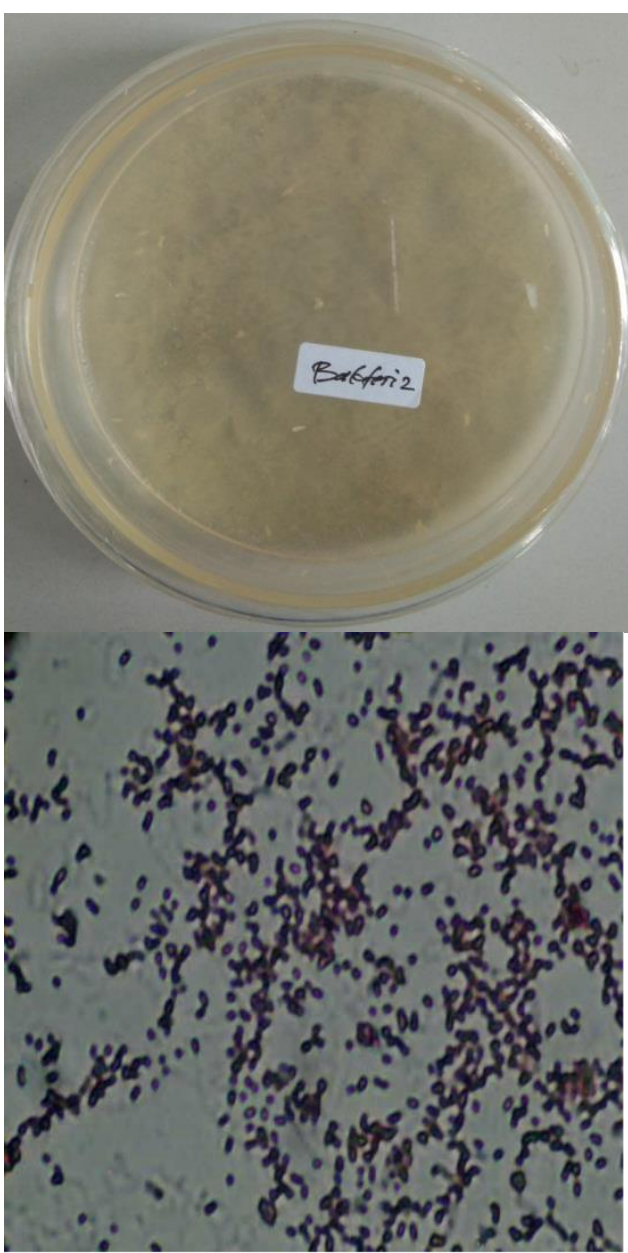

Figure 6. Coccus bacteria with negative red color (gram).

According to Campbell (2009), bacterial populations grow very quickly when they are supplied with nutrients and environmental conditions that allow them to thrive. Through this growth, different types of bacteria will sometimes produce colonies that are distinctive in appearance. Some colonies may be colored, some are circular, while others are irregular. Colony characteristics (shape, size, color, etc.) which are termed "colony morphology" are typical for each type of bacteria.

The number of colonies found in both plates had the same number of 1 colony. This is due to nutritional factors that affect the number or proliferation of bacterial colonies. In order to survive in nature, microbes (including bacteria) must be able to grow and reproduce quickly, this may be achieved if the bacteria can take nutrients efficiently because in nature there is competition for limited amounts of nutrients Campbell (2009).

\subsubsection{Nematodes Foundi On Post Coal Mining Land} in Makroman Village.

From the results of the research that has been carried out, it is found that 1 (one) nematode species, namely Pratylenchus sp. This species was found in 
soil samples vegetated with acacia and sengon plants.

\subsubsection{Pratylenchus sp.}

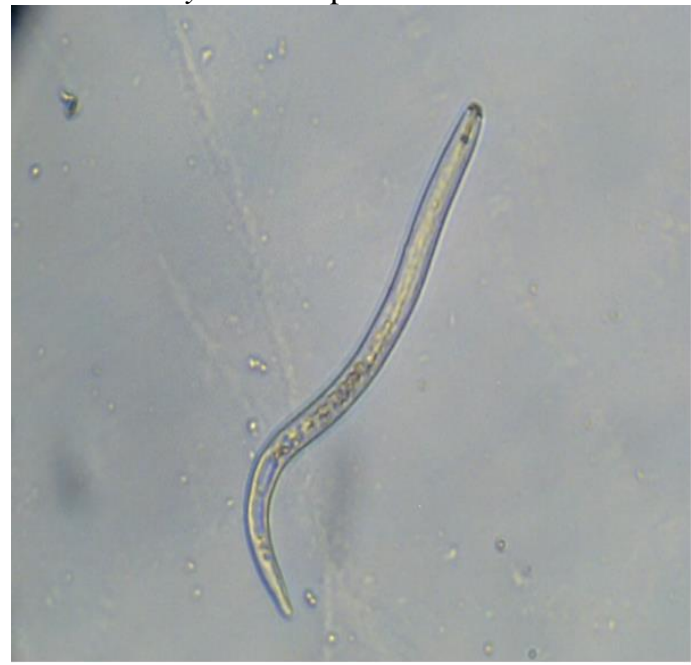

Figure 7. The nematode Pratylenchus sp.

Pratylenchus sp. is a nematode that is very small among other plant parasitic nematodes. The width of the body of this nematode is between $40 \mathrm{~m}$ to $160 \mathrm{~m}$, with a body length of $0.4-0.7 \mathrm{~mm}$, while the body diameter is $20-25 \mathrm{~m}$.

Based on the results obtained that in the postcoal mining soil in the research location, it was found that only4 (four) different types of fungi, namely Trichoderma sp, Penicillium sp, Fusarium sp, and Aspergillus sp. The type of bacteria obtained based on the results of the study there are two types of bacteria, the first is round-shaped bacteria (Coccus) and has a negative gram, the second type of bacteria is rod-shaped bacteria (Bacilli) and has a gram-negative color and the type of nematode obtained based on the results of research from postmining soil samples contained only one type of nematode, namely the nematode Pratylenchus sp.

Root wound nematode (Pratylenchus sp.) is a nematode that is very small among other plant parasitic nematodes. The size of the length and width of the body is the smallest after Paratylenchus $\mathrm{sp}$. the body width of this nematode is between $40 \mathrm{~m}$ to $160 \mathrm{~m}$, with a body length of $0.4-0.7 \mathrm{~mm}$, while the body diameter is $20-25 \mathrm{~m}$ [14].

According to Shurtleff et al. (2000), the nematode Pratylenchus sp. have a body length of less than $1 \mathrm{~mm}$. If this nematode dies because it is treated with heat slowly, then the body is slightly bent on the ventral side. The head is low and flat, when observed under a stereoscopic microscope, the anterior end looks like a flat black hat. Shurtleff et al. (2000), suggested that the length of the Pratylenchus stylet ranged from 13-20 m [15].

The nematode Pratylenchus sp. has an oval median bulb and is very muscular. In females, tail subcylindrical, conoid. Smooth annulated body, without mukron. Stock terminal on the tail. These nematodes are mobile endoparasites, and all stages are present in the cortical tissue of the host [16]. The nematode Pratylenchus sp. is a nematode that can cause damage to various important crops such as pineapple, orange, potato, tobacco, cotton, corn, banana, coffee, apple, sweet potato, tea, avocado, and yam, nuts and strawberries, and is cosmopolitan so it can be found in various hot and tropical climates Chen (2007). Nematodes can also be associated with fungi and bacteria such as Pythium, Rhizoctonia, Phytophthora, Pseudomonas, Aspergillus and Fusarium, Aphanomyces euteiches, Clindrocarpon radicicola, Trichoderma viride and Verticilium arbo-atrum and dahlie. As a result of this symbiosis, the damage caused can be even more severe [17].

According to Siddiqi (2000) and Dropkins, (1996), the classification of nematodes Pratylenchus sp. are as follows: Kindom: Animalia; Phylum: Nematodes; Class: Secernentea; Subclasses: Tylenchia; Order: Thylenchida; Family: Pratylenchidae; Genus: Pratylenchus; Species: Pratylenchus sp [18].

Microorganisms found in post-mining soil in Makroman sub-district are relatively few, and are the types of microbes that are able to survive in soil that is relatively unsupportive for microbial life due to poor soil conditions [19]. As explained by Cavender et all., (2014), Coyne, M. S, (1999) and Djayakirana, (2002) mentioned that the impact of damage caused by mining activities can be seen in the environmental damage that occurs. The impact of the damage is a decrease in land quality as indicated by a decrease in the physical, chemical and biological quality of the soil [20]. The low activity of soil microorganisms is due to the influence of various microbial environmental factors such as a decrease in soil $\mathrm{pH}$, soil moisture, organic matter content, soil holding capacity to water and soil structure [21].

\section{CONCLUSION}

Based on the results of the research that has been carried out, it can be concluded that the types of fungi obtained based on the results of the study contained 4 (four) different types of fungi, namely Trichoderma sp., Penicillium sp., Fusarium sp., and Aspergillus sp.; Types of bacteria obtained based on the results of the study there are two types of bacteria, the first is round bacteria (Coccus) and has a gram negative, the second type is rod-shaped bacteria (Bacilli) and has a gram negative color; and there was only one type of nematode, namely the nematode Pratylenchus sp.

\section{REFERENCES}

[1] Pribadi, A. 2012. Reclamation of ex-coal mine land. Faculty of Agriculture. Veterans National Development University. Yogyakarta. 
[2] Purnamayani, R., J. Hendri, H. Purnama, Busyra, N. Imdah. 2015. Year-end Report on the Study of Post-Coal Mining Land Reclamation Technology in Jambi Province. Jambi Agricultural Technology Research Center. Jambi. [9] Alexopoulos, CJ, and Mims, CW 1979. Introductory Mycology Library Of Congress Cataloging in Publication Data. United States of America.

[3] Rahmawati. 2002. Restoration of Ex-Mining Land Based on Ecological Rules. Faculty of Agriculture, University of North Sumatra, Medan. [13] Campbell, NA, JB Reece., LA Urry., ML Cain., SA Wasserman., PV Minorsky., and RB Jackson. 2009. Biology Ninth Edition. Pearson Education Inc, Benjamin Cummings. San Francisco.

[4] Subowo, G. 2011. Environmentally Friendly Open System Mining and Post-Mining Reclamation Efforts to Improve the Quality of Land and Soil Biological Resources. Soil Research Institute. Bogor.

[5] Adman, B. 2012. Trial of Planting Ten Types of Local Pioneers in Post-Coal Mining Pt. Singlurus Pratama, East Kalimantan. Research Institute for Natural Resources Conservation Technology. East Kalimantan.

[6] Cooke, JA, and MS Johnson. 2002. Ecological Restoration Of Land With Particular reference To The Mining Of Metals And Industrial Minerals: A Review Of Theory and Practice. Environmental Review 10:41-71.

[7] Domsch KH, W. Gams., TH Anderson. 1980. Compendium Of Soil Fungi. Volume I. Academic Press. London.

[8] Nurhayati, H., 2001. Effect of Trichoderma sp. Against Infectiousness and Survival of Sclerotium roflsii on Chili Roots. Thesis of the Faculty of Agriculture UNTAD, Palu

[9] Alexopoulos, CJ, and Mims, CW 1979. Introductory Mycology Library Of Congress Cataloging in Publication Data. United States of America.

[10] Robert, A. Samson, Ellen S. Hoekstra, and Connie AN Van Oorshot. 1984. Introduction to food-borneo fungi. Institute of The Royal. Netherlands.

[11] Black, JG 1999. Microbiology: Principles and explorations. 4th ed. John Willey \& Sons, Inc., New York: xxiv + 786 pp Campbell 2008

[12] Robinson, Richard. 2001. Biology Macmillan Science Library. Macmillan Reference. USA.
[13] Campbell, NA, JB Reece., LA Urry., ML Cain., SA Wasserman., PV Minorsky., and RB Jackson. 2009. Biology Ninth Edition. Pearson Education Inc, Benjamin Cummings. San Francisco.

[14] Agrios, GN 1997. Plant Pathology Fourth Edition, Academic Press. New York.

[15] Shurtleff, MC and Averre, CW 2000. Diagnosing Plant Diseases Caused by Nematodes. The American Phytopathological Society. APS Press.

[16] Siddiqi, MR 2000. Tylenchida Parasities of Plants and Insects. CABI Publishing. New York. USA.

[17] Chen, X,. Liua, M. Hua, F., Maoa, X., and Huixin, L. 2007. Contribution of soil microfauan (protozoa and nematodes) to rhizosphere ecological function. Acta Ecologia Sinica 27(8): 3132-3143 .

[18] Dropkin, V, H. 1996. Introduction to Plant Nematology. Universitas Gadjah Mada University Press. Yogyakarta.

[19] Cavender N, Byrd S, Bechtoldt CL, Bauman JM. 2014. Vegetation Communities of a Coal Reclamation Site in Southeastern Ohio. Northeastern Nat 21 (1): 31-46

[20] Coyne, Mark S. 1999. Soil Microbiology: An Exploratory Approach. USA : Delmar Publisher.

[21] Djajakirana, G. 2001. Soil Damage as Impact of Agricultural Development. Department of Soil, Faculty of Agriculture, Bogor Agricultural University. Bogor. 